\title{
CHANCES FOR THE DEPRESSED CENTRAL EUROPEAN REGIONS OF THE EUROPEAN UNION TO DEVELOP: CAN SHARED SERVICE CENTRES BE THE DRIVING FORCE?
}

\author{
CSABA Roland RUZSA ${ }^{1}$
}

University of Pécs (Hungary)

\begin{abstract}
Shared Service Centres (SSCs) may lead to job creation in the professional field in the less developed EU region. By 2015, in the CEE region, the number of employees in this sector exceeded 335000 and the trend tends to be increasing heavily. Looking at the actual numbers of the sector, the author tries to define the main decision making factors for a SSC to settle down in the region. The paper focuses on the evaluation of possibilities, arguing if the development of the SSC sector can continue creating jobs in this region. KEYWORDS: regional development, education, technological change, economic development, growth, shared service centres.
\end{abstract}

JEL CODES: O10, O30, R11.

DOI:

\section{Introduction}

The purpose of this paper is to analyse the opportunities of the Shared Service Centres (SSCs) in Central European countries, including Hungary. It is obvious that a significant amount of new educated workplaces has been created in the CEE countries' labour market in the last decade. Language skills and the presence of educated workforce provided very good starting conditions to establish SSCs in the region. The author of this paper tries to define whether this trend can continue and new centres will be opened. Also, there is a seek to define the main factors that are necessary in the region to continue this labour force creation process for educated workforce.

The object of research is to analyse whether new SSCs can be established in the CEE region; it is followed by a short introduction of the current SSC situation in general at the regional and the global level.

The objectives of research are to show the current number of the SSCs market in Central European countries and also in Hungary, in its SSC sector. The author presents trends in this sector too.

The task of research is to define the key factors determining a decision on the SSC site location. The second part of the paper summarises how Hungary is corresponding to these key factors.

The paper is based on a literature survey as a research method. From a methodological perspective, companies opening up SSCs in the region have already set up forums with universities where these topics are frequently discussed. Economic institutions and the major advisory firms also provide economic reports on the labour market changes and FDI investments in the region, where significant amount of data and publications are available. Furthermore, theoretical studies on the labour market and published analyses also provide significant research topics that are helpful to collect, compare and analyse data.

1 Csaba Roland Ruzsa - PhD student, Regional Policy and Economics Doctoral School, Faculty of Business Administration, University of Pécs, Hungary

Scientific interests: regional development, economic development, site location survey

E-mail: ruzsa.csaba@pte.hu

Tel. 0036308161419 
From von Thünen to Krugman (Bacsi, 2007: 26-35), economists have tried to understand what types of economic activities have been located at a given point in the world, and why (Dubé et al., 2015). From the outset, the location theory emphasised the role of distance, economies of agglomeration, and rent seeking in the location of firms and industries (Lengyel, 2005: 3). In the last decade, we can see a new development of organisational and financial structures in the global world called Shared Service Centres (Acuman, 2001: 1).

The author of this paper tries to define the new ways these centres have been developing (Deloitte, 2015) in the CEE region.

\section{Shared Service Centres - a new way for company restructuring and job creation}

The shared service is a new way of organising business operations within multi-national companies. In Europe, this phenomenon appeared in the middle of the last decade. As a predecessor of this phenomenon, we can define the so-called relocation of factories to cheap labour countries. However, these new centres are mainly focused not on cheap labour, but they are based on qualified labour.

One of the main reasons of this phenomenon, of course, was the continuous seek to decrease costs within international companies. The fields of operations where the costs may be decreased vary in three different groups:

- Financial and HRM back-office costs,

- IT back-office costs, and

- R\&D services.

Companies usually focus on the first two groups, however, in the last few years the first "outsourced" $R \& D$ centres also appeared in the market. The way of operation in these centres rely on the annual financial scheme where the rendered services are paid by the headquarters to the centres at a third-party price.

\subsection{Reasons for a SSC from a company's point of view}

Analysing the main factors that underline the decision of a multinational company to establish a Shared Service centre, it is obvious that companies intend: to acquire new qualified labour and at the same time to increase quality simultaneously decreasing the running costs. A multinational company has to determine the scope of services that are worth to be outsourced, and it is part of the preliminary phase. The main factor in this process is to determine whether these processes can be standardised and centralised in a new SSC (Oshri, 2012: 91-96). In the next phase, there have to be determined the exact processes that can be outsourced (Thomas, 2013: 25-30). Usually, when a new SSC is formed, then it is opened as a new legal entity within the company group, and its own management and operational rules have to be determined (Wang, 2007: 284-288).

\subsection{Requirements to establish a SSC from a business perspective}

The first step towards the planning of a SSC is to determine which services will be provided. Generally, all transactional processes which can be standardised are suitable for a migration into a SSC. The second step is to conduct an analysis determining which process steps should be performed by the SSC and which should remain decentralised. SSCs are often separate business units with their own organisational and operational structure. Therefore, a SSC may even decide to transfer the selected processes to an external service provider (Chen, Moor, 2009).

To deliver the services defined in service level agreements (SLAs) (Colman, 2006: 37-39), it is essential to implement an adequate IT infrastructure, a workflow management system and an information management system (Alvarez et al., 1999: 1). Focusing on these major implementation issues ensures that all services and communications provided are performed via clearly defined interfaces (Towle, 2015: 83-85). 


\section{The SSC phenomenon in the world}

Based on the above requirements, many companies have already decided to create a SSC. These companies belong to different industries. As an example, the author of this paper collected a list of companies that have already decided on a SSC: 3M, AIG Insurance, Allied Signal, American Express, Amoco, BASF, Bertelsmann, Bristol Myers, British Airways, Chase Morgen Grenfell, Ciba Speciality Chemicals, Citibank Bankers, Coca Cola Company, Trust, Delta, Diageo, Eaton, EDC Scicon, Ericsson, ExxonMobil, Fidelity, Ford, GE Medical Systems, Girobank, Gothenburg, Guinness, Hewlett-Packard, Hewlett-Packard, Hughes Training, Interox, Kellogg's, Microsoft, Merrill Lynch, Polaroid, Rubbermaid, Scottish Amicable, Seagram, Sterling Commerce, Unisys, United Distillers, Volkswagen-Audi, Volvo, Wang, Whirlpool, Woodchester (Novinite.com, 2013; Deloitte, 2015: 3., Ernst and Young, 2014). As it can be seen, many industries are represented in the list. This phenomenon has become a normal economic pattern for companies operating in many countries. Looking at Europe, one can identify which countries are the main SSC countries and one can identify them based on the number of SSCs in the CEE region as well. The map below shows the main cities that have attracted a significant number of SSCs (Figure 1).

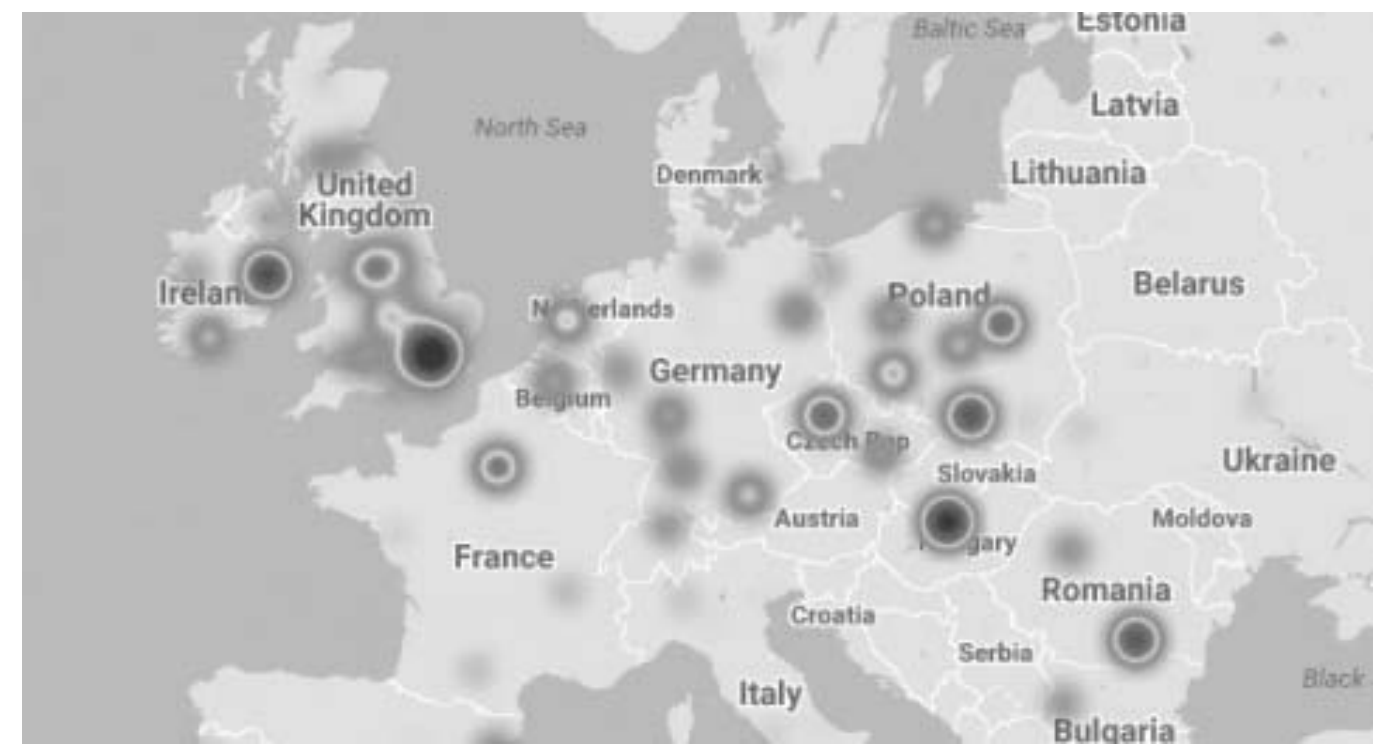

Fig. 1. European Shared Services Job Market 2017

Source: EMEA Analytics: SSON Analytics.

\section{The SSC phenomenon in Central Europe}

Central and Eastern Europe has experienced a massive growth in shared services and outsourcing activity over the past 15 years. Emerging countries such as Bulgaria, Lithuania and Croatia are seeing huge growth, although well-established Poland still has most of the centres. Hungary has gained several centres as well (Ernst and Young, 2014: 4-21).

In this region, over 15 years there has been developed a mature and experienced business services sector. There are around 1000 centres employing 335,000 professionals in Q1 2015. The Compound Annual Growth Rate $\left(\mathrm{CAGR}^{2}\right)$ (Belvedere, 2017: 198) in employment has been 17\% over the past seven years, and it is two times faster than its growth in India (Deloitte, 2015: 1). There is also a secured supply of strong fresh graduate talents and a line of experienced outsourcing senior management talents. Furthermore, there is a broad diversity of city locations with dedicated talent profiles, labour and real estate cost arbitrage. A

2 Compound Annual Growth Rate $(C A G R)$ is the mean annual growth rate of an investment over a specified period of time longer than one year. 
quickly changing structure of services from back to front office functions is available, proving high quality and stability over time.

For multi-national corporations there have been worked-out destinations of global services command centres with a size of an average complex often exceeding $3.000 \mathrm{FTEs}^{3}$ (Deloitte, 2015: 1). The economic and political stability across the region is coupled with the EU legal code and the regulatory environment. In addition, there are also attractive investment incentives in the region due to the available EU structural funds.

\section{Site location for multinational companies within Europe - main factors that influence the decision process}

There are sought ways how new SSCs can be attracted to this region. Based on interviews with Big Four experts and the literature survey, scholars managed to identify seven factors that are essential when deciding where to site SSC operations. The author has looked at the future trends of these factors in the Central and Eastern European region. Below are presented the main seven factors (Borman, 2012).

\subsection{Financial incentives}

In this respect, the focus mainly is not on the EU subsidies that a company could gain in a location process, but rather on the financial and tax environment of a country. The governments of Central European countries compete to make their countries more and more attractive to foreign investors (Deveraux, Griffith, 2003). They have taken measures such as tax reforms that would encourage business development. For example, Estonia started a 19\% flat-tax regime in the mid-90s, Romania, Poland and Hungary cut taxes under 20\% for corporations while Latvia and Lithuania have instituted a low $15 \%$ flat tax on all income, corporate and personal (Ernst and Young, 2014). These incentives are not applicable to internal shared services functions, which are non-revenue generating. However, for more complex internal arrangements, where shared service centres operate as profit centres, these changes make for a very positive tax position. These taxes are now well embedded and there are no indications that they are going to be modified drastically. Looking at the regional aspects, the less developed regions may also provide infrastructural developments supported by the central government that may be attractive to shared service companies, e.g., such as road or infrastructure developments.

\subsection{Language skills}

The total number of English speakers in Central and Eastern European countries is estimated to be over 30 million, while the number of German speakers is over 16 million (Eurostat, 2015: 63).

In terms of foreign language skills (other than English) the countries of the CEE region can be divided into three main groups of counties according to the prevalent foreign language:

- German language: Poland, Czech Republic, Slovenia, Hungary, Romania.

- Russian language: Latvia, Lithuania, Poland, Bulgaria, Czech Republic, Slovakia.

- Latin languages (French, Spanish, Italian): Romania.

If one looks at the number of English speakers in the region by countries, he/she may find the following numbers:

This data shows that the number of professionals employed in 2015 (338 000) can still be increased heavily in the coming years.

An FTE of 1.0 is equivalent to a full-time worker or student, while an FTE of 0.5 signals half of a full work or school load. 
Table 1. Number of English speakers in the CEE region by countries

\begin{tabular}{|l|c|}
\hline \multicolumn{1}{|c|}{ Country } & Number of English Speakers (mill.) \\
\hline Poland & 10.8 \\
\hline Romania & 6 \\
\hline Czech Republic & 2.2 \\
\hline Hungary & 2.1 \\
\hline Bulgaria & 1.9 \\
\hline
\end{tabular}

Source: Eurostat. Key Figures on Europe (2015: 64-67).

\subsection{Labour turnover}

A low labour turnover is a very desirable thing for any shared services centre as it shows not only the loyalty of employees, but also leverages the investments in employee development to the maximum. Many of the CEE countries are positioned in the most favourable areas benefiting from both a low labour turnover and low labour cost. The business process outsourcing (BPO) industry, however, generally has higher labour turnover rates than the overall average per the economy, for example: $30-35 \%$ in India, $20-30 \%$ in Eastern European Centres, $20 \%$ in the UK and 15\% in South Africa. Shared service centres themselves are reporting varied effects (Deloitte, 2015: 1). Whilst in major cities these turnover rates are often exceeded, with careful management these levels can be reduced. For instance, in the case of a major centre opened by a European electronics group, they have managed to keep the levels around 10\% per annum. However, turnover ratios depend a lot on the chosen location within the CEE countries. In the most populated areas, leaders of shared services now admit that the costs of reducing this turnover is the inevitable cost of operating in the region.

\subsection{Office availability and costs}

Even though real estate costs have been growing constantly during the past years in all CEE countries, these locations are still attractive compared to others in Asia or Western Europe.

A decade ago finding quality business spaces in most Eastern European countries was a challenge, especially outside the capitals. Today, the situation is changed as large scale real estate developments, such as business and technology parks, as well as numerous office buildings, have been completed. Office spaces are now available at reasonable costs in capitals, and smaller towns in all CEE countries. In the last decade, in the site search process there can be seen a new phenomenon, the multinational companies tend to leave the capitals and settle down usually in agglomeration or even in the so-called middle size cities on the European scale. The author collected some cases where these centres appeared in these territories (Ernst and Young, 2014) (Table 2).

Table 2. SSCs in Central European cities outside capitals

\begin{tabular}{|l|c|c|}
\hline \multicolumn{1}{|c|}{ Company } & City / Town & Country \\
\hline ProRate Service Centre & Nitra & Slovakia \\
\hline KBC Shared Service & Brno & Poland \\
\hline Sappi Global SSC & Krakow & Poland \\
\hline Accenture & Lódz & Poland \\
\hline Hewlett Packard & Wroclaw & Romania \\
\hline Office Depot SSC & Cluj-Napoca & Hungary \\
\hline ITSH (DT) & Pécs & \\
\hline
\end{tabular}

Source: the author's own research. 
Based on the above, one can see a significant increase over the last five years in building new offices that reflect the needs generated by the SSC phenomena. In smaller cities, the general office used to be available in the inner cities and the parking facilities were not sufficient. In this new process, the SSCs require the so-called A class offices that are green and smart buildings and provide enough parking places. As a result, these new office buildings in new locations can even reach the space of 30,000 to 100,000 sqm. Besides, the availability of labour, the number and size of available office buildings has also become a key factor in the site search decisions (Dantons, 2015).

\subsection{Labour available in SSCs for university graduates in Central Europe}

The experience of the past two decades shows that the post-communist universities and colleges provided a significant number of educated people that could not find a workplace in the post-communist economical structures, since the new structures were not financially viable enough to employ them. Therefore, international SSCs could find a significant amount of educated workforce in the post-communist countries such as Hungary, Romania, Slovakia, Poland, and Bulgaria. In addition, language skills were also important in the post-communist university education system, therefore, the language skills were also available. In the last decade, these skills supported the continuous growth of the SSCs presence in the Central Eastern European region. Comparing the EU member states that joined the EU in 2004 and the so-called "old" member states, it is obvious that the education system of the CEE countries deliver a higher rate in the number of tertiary educated workforce ( 8.59 per 1000 inhabitants) than that of the "old" EU member states (7.47 per 1000 inhabitants). The public spending figures show that the CEE countries may be more efficient in this field than the old EU states and the US, although the new states also spend the same proportion (approx. 5.3\%) of their annual budget for these purposes.

However, the migration of labour force to western European countries from eastern countries created a significant number of new jobs in different industry sectors in the CEE countries, meanwhile it limited the number of available workforce for the SSCs (Eurostat, 2015). The size of migration of labour force from eastern countries to western European countries is immense. This is the main phenomenon in the decreasing unemployment rate of the eastern countries. In Hungary, the estimates show that 5-600,000 people could leave Hungary to work abroad within the EU. Looking at the Polish estimations, one can even count up to 2.4 million of people leaving Poland to work abroad. Moreover, statistical experts calculate that due to the economic crisis that started in 2008 in Romania, at least 2.7 million of people left Romania to work abroad since the beginning of the last decade.

However, there are several signs that some people return to their home country for work. One of the main reasons of return is the Brexit fear and the appearance of western level payments in Central European countries. The SSCs can already provide a level of payment that encourage people to go back to work to their home country. Since many young and single people went abroad for work, they are also more flexible and ready for changes, even if these changes may be seen as a "step backwards".

Analysing labour market changes in the CEE countries, it can be identified that these markets lack not only the skilled labour, e.g., for assembly plants, but also, the available number of educated labour force became very small compared to that of a decade ago. Therefore, if companies intend to set up more SSCs in the region in the coming years, they will probably face the challenges of available educated workforce. Besides hiring activities, the companies need to co-operate in educating labour. Furthermore, companies operating with the SSCs should also build new kind of relationships with the CEE region universities in order to obtain necessary amount of educated labour (Orion Partners, 2008).

In case these companies are involved in education co-operation with the CCE institutions, the educated workforce could deepen its specific knowledge relating the topics that could be outsourced to SSCs such as human relations, book-keeping with finance, IT and procurement. This could lead to the higher quality of service that the SSC workforce could deliver. 


\subsection{Existing location or new location for a SSC in the CEE Region}

In the decision process on a site location for a SSC, companies usually at first look, whether they have already any strong and viable business history in that region or even already have the own site for several functions (e.g., a branch or a production facility). The experience that companies have already gained in the region may have a significant impact on the site location decision process. Furthermore, companies also look at the way how business is carried out in the region, and try to identify the main business patterns. In addition, companies evaluate the main types of costs they have to bear, such as overheads and real estate expenses. In the site search process, having determined the above-mentioned factors, companies will look at general infrastructural conditions. These infrastructural factors are mainly the number of available office buildings, areas, IT infrastructure and auxiliary services in the region (Schulz, 2009). Companies usually try to find a region where traffic conditions are acceptable, office spaces are available, since they assume that in such a region they may find the necessary labour easier than in a region where these conditions are rare. As has been mentioned above, if companies have an operating history with a plant in a certain region, they may already have knowledge of the main patterns how to make business in that region. This background knowledge usually has the main impact on the decision-making process (Thomas, 2013).

\section{Conclusions and future expectations}

Having evaluated the key factors above, one can presume that as long as political and economic stability is present in the CEE region and the EU structural funds flow into the CEE economies, the economic prosperity may continue to last for the next decade as well. Looking at predictions of economic think tanks for national economies, it can be assumed that the economic growth will sustain in the CEE region in the coming years and this will help avoid major economic shocks in the region (Nguyen et al., 2013). The availability of workforce is influenced by skills levels, unemployment and migration. These will remain volatile factors, particularly as migration levels respond to slowdowns in growth across the developed economies of Europe in the next five years. However, the depth of the labour force and the skill base in the region indicates that though pay inflation may again start to rise in pace, the underlying workforce will remain available in sufficient numbers to support long-term operations in the region (Marciniak, 2013).

The future growth depends on the ability to attract centres that provide more advanced and sophisticated services. Two global trends will work in the CEE's favour in this transition. First, the global market for outsourced business process services is expected to continue growing, about $10 \%$ annually, to a projected value in 2020 approaching USD 100 billion (Orion Partners, 2015).

In addition, basic, lower value-added services are naturally migrating toward the lowest-cost locations, such as India and the Philippines. At the same time, investors are increasingly valuing near-shoring solutions for more sophisticated processes, bringing them closer to home (National Association of Software and Services Companies, 2015).

The following areas are potential sources of growth in advanced business services in the CEE region:

- Middle-office for banks and insurance companies: broad spectrum of end-to-end processes, including loan and mortgage process servicing, fraud detection, policy and claims handling;

- Advanced IT programming: software development, IT systems administration and integration services, IT infrastructure hosting;

- Supply-chain and logistics coordination centres: supply-chain optimization centres for FMCG (fastmoving consumer goods), logistics;

- Business research and analytics: high value-added business research for professional firms and financial institutions, and business analytics including big data advanced customer-base analytics;

- Research and development: contract research across many industries and technology fields. 


\section{References}

Acumen Alliance (2001). Shared Services - What is Shared Services [online]. Available at: http://www.acumen.com.au/ sharedservices [Accessed 10 October 2006].

Alvarez, E., Blansett, T., Counto, V., Dunn, M., Nielson, G., Niekirk, D. (1999). Beyond Shared Services: E-Enabled Service Delivery. Booz-Allen \& Hamilton Incoporated Report.

Available at: https://www2.deloitte.com/content/dam/Deloitte/dk/Documents/finance/Deloitte-SSSurvey-Interactive. pdf, p. 22-30.

Bacsi, Z., Pannon, E., Forman, B., Corvinus, E., Káposzta, J., Szent, I. E., Nagyné, M. M., Szent, I. E., Péter, B. (2007). Regionális Gazdaságtan. DE AMTC AVK.

Belvedere, V., Grando, A. (2017). Sustainable Operations and Supply Chain Management. Wiley, p. 242.

Borman, M., Janssen, M. (2012). Critical Success Factors for Shared Services: Results from Two Case. System Science (HICSS), 45 th Havaii International Conference on System Science, p. 2512-2518.

Campbell, A., Kunisch, S., Müller-Stewens, G. (2011). To Centralize or Not to Centralize? McKinsey Quarterly. Available at: http://www.mckinsey.com/business-functions/organization/our-insights/to-centralize-or-not-to-centralize.

Cédric, L. A. (2016). Local Labor Markets in a New Economic Geography Model. The Review of Regional Studies, Vol. 46, No. 1, p. 1-3. Available at: http://journal.srsa.org/ojs/index.php/RRS/article/view/46.1.1/pdf_1.

CEE Investments Report. (2015). Dantons. Available at: file://CC:/Users/rucaaa.k.jpte/Downloads/CEE\%20Investment\%20Report\%202016_Mission\%20to\%20Outperform.pdf.

Chen, M. X., Moore, M. O. (2009). Location Decision of Heterogeneous Multinational Firms, p. 5-8. Available at: https://www2.gwu.edu/ iiep/assets/docs/papers/Chen_Moore_\%20IIEPWP2.pdf

Colman, R. (2006). Service Level Agreement: A Shared Service Cornerstone. CMA Management, Vol. 80, Issue 3, p. 37-39.

Deloitte Consulting LLP. (2015). 2015 Global Shared Services Survey. Survey Results.

Devereux, M. P., Griffith, R. (2003). International Tax and Public Finance. Evaluating Tax Policy for Location Decisions, Vol. 10, p. 107-126.

Dubé, J., Brunelle, C., Legros, D. (2015). École Supérieure d'aménagement du territoire et de développement régional (ÉSAD), Université Laval, Canada, Institut National de la recherche scientifique (INRS), centre Urbaninsation, Culture, et Société (UCS), Canada, Laboratoire d'économie de Dijon (LED), Université de Bourgogne, France. Location Theories and Business Location Decision: A Micro-Spatial Investigation of a Nonmetropolitan Area in Canada, p. 2-8.

Ernst and Young. (2014). Attractiveness Survey, Europe 2014, Back in the Game 2014. Available at: http://www.ey.com/Publication/vwLUAssets/EY-2014-european-attractiveness-survey/\$FILE/EY-2014-european-attractiveness-survey.pdf.

EMEA Analytics: SSON Analytics. (2017). Available at: https://www.sson-analytics.com/emea-analytics.

Eurostat. (2015). Key Figures on Europe. European Communities, p. 64-67. Available at: http://ec.europa.eu/eurostat/ documents/3217494/7072644/KS-EI-15-001-EN-N.pdf/318ee884-50d6-48f0-b086-4410da85d6b6.

Herbert, I., Seal, W. (2013). The Rise of Shared Service Centres Is a Revolution That's Going Under the Radar. Financial Management, $p .14$.

Lengyel, I. (2005). On the Interpretation of Territorial Competition and Competitiveness. In G. Horváth (ed). Competitiveness of the Hungarian Regions and Places in the European Economic Space. Centre for Regional Studies, Hungarian Academy of Sciences, Pécs, p. 37.

Marciniak, R. (2014). Vision about Hungarian Sourcing Market. Economics Questions, Issues and Problems, Vol. 2, p. 157-164. Published by International Research Institute, Slovakia.

Meijerink, J. G., Bondarouk, T. (2013). Exploring the Central Characteristics of HR Shared Services: Evidence from a Critical Case Study in the Netherlands. International Journal of Human Resource Management, Vol. 4, No. 3, p. 487-513.

National Association of Software and Services Companies (NASSCOM). (2015). Business Services in Central \& Eastern Europe. The CEE Business Services Landscape. Available at: nasscom.in.

Nguyen, C. Y., Sano, K., Tran, T. V., Doan, T. T. (2013). Firm Relocation Patterns Incorporating Spatial Interactions. Annals of Regional Science, Vol. 50, p. 685-703.

Novinite.com. (2013). Coca-Cola Opens Finance Shared Service Center in Sofia. Available at: http://www.novinite. com/articles/149436/CocaCola+Opens+Finance+Shared+Service+Center+in+Sofia [Accessed June, 18, 2015].

Orion Partners. (2008). Trends in Shared Services in Central and Eastern Europe. The Coming of the New Wave, p. 2-35.

Oshri, I. (2012). Who Moved My Shared Service Centre? Journal of Information Technology Teaching Cases, Vol. 2, p. 87-97.

Ramphal, R. R. (2011b). A Quality Framework for Services in Shared Service Environments. Journal of Contemporary Management, Vol. 2, p. 223-238.

Schulz, V., Hochstein, A., Uebernickel, F., Brenner, W. (2009). Definition and Classification of IT-Shared-Service-Center. Americas Conference on Information Systems (AMCIS), p. 5-11. 
Soalheira, J., Timbrell, G. (2014). What is Shared Services? In T. Bonderaux (ed.). Shared Services as a New Organizational Form. Emerald Group Publishing Limited, p. 67-75.

Thomas, R. (2013). Shared Services Generating Value for Business. In F. Keuper, K. Lueg (eds.). Finance Bundling and Finance Transformation - Shared Services Next Level. Wiesbaden, Springer, p. 25-32. Available at: http://www. lusem.lu.se/library [Accessed March 31, 2016].

Towle, R. (2015). Taming the Reporting Beast Through Shared Services. Financial Executive, Vol. 31, No. 3, p. $83-85$.

Turle, M. (2010). Shared services: An Outline of Key Contractual Issues. Computer Law \& Security Review, Vol. 26(2), p. $178-184$.

Wang, S., Wang, H. (2007). Shared Services Beyond Sourcing the Back Offices: Organizational Design. Human Systems Management, Vol. 26(4), p. 284-288.

\title{
MAŽIAU IŠSIVYSČIUSIŲ CENTRINĖS EUROPOS REGIONU VYSTYMOSI EUROPOS SĄJUNGOJE GALIMYBÉS: AR PAS- LAUGU CENTRAI GALI TAPTI ESMINE JËGA?
}

\author{
Csaba Roland Ruzsa \\ Pécs universitetas (Vengrija)
}

\section{Santrauka}

Paslaugų centrai gali sukurti naujas darbo vietas mažiau išsivysčiusiuose Europos Sajungos regionuose. 2015 metais darbuotojų skaičius šiuose sektoriuose išaugo iki 335000 ir panašu, kad dar augs. Straipsnyje siekta pagrịsti tokių paslaugų teikimo naudą mažiau išsivysčiusiems regionams pritraukiant dideles tarptautines organizacijas, vertinamos ir bendrų paslaugų centrų kūrimo regionuose galimybès.

Atlikus analizę nustatyta, kad centriniuose regionuose šias paslaugas dar galima plèsti. Taip atsiranda galimybė mažiems bankams ir draudimo bendrovèms prisijungti prie didesnių ir teikti papildomas paslaugas; administruoti informacinių technologijų centrus, kurie vykdytų informacinių technologijų priežiūrą; logistikos srityje kurti koordinavimo centrus, kur būtų optimizuojamos vertẻs kūrimo grandinès; atliekami verslo tyrimai ir analizè, siekiant kurti ne tik esamų mažų organizacijų pridètinę vertę, bet ir didesnèms organizacijoms pasinaudoti esamu moksliniu potencialu už mažesnè kainą bei žinant vietines subtilybes.

Reikia paminèti, kad šiuose regionuose gerokai išaugo kvalifikuotų darbuotojų skaičius, nes universitetai parengė nemažai atitinkamų specialistų. Tokie bendrų paslaugų centrai ir pradèti kurti, iškeliant tokias daug žinių reikalaujančias paslaugas ị mažiau ekonomiškai išsivysčiusius regionus. Jie pradèti kurti sostinèse, kur yra pakankamai išsimokslinusių žmonių, galinčių dirbti tokius darbus, be to, yra būtina infrastruktūra, galima nuomotis patalpas. Šiuo atveju darbuotojų samdymo išlaidos šiek tiek mažesnès negu „motininėse“ šalyse: pigesnè patalpų nuoma ir mažesni darbuotojų atlyginimai skatina tokias organizacijas kurtis svetur.

Antrajame etape jau galima kurti tokius centrus mažesniuose miestuose, kur yra mokymo institucijos, kuriose rengiami informacinių technologijų ar kiti paslaugų centrų funkcijas gebantys atlikti specialistai. Tiesa, kartais tokiems centrams steigtis pritrūksta biuro patalpų. I tai turètų atkreipti dèmesị tų miestų savivaldybès.

PAGRINDINIAI ŽODŽIAI: regionu vystymas, švietimas, technologiniai pokyčiai, ekonominis vystymasis, augimas, paslaugu centrai. 